University of Nebraska - Lincoln

DigitalCommons@University of Nebraska - Lincoln

Faculty Publications: Department of

Entomology

Entomology, Department of

2003

Imported Longhorned Weevil (Coleoptera: Curculionidae) Injury to

Soybean: Physiological Response and Injury Guild-Level Economic Injury Levels

\author{
Thomas E. Hunt \\ University of Nebraska-Lincoln, thunt2@unl.edu \\ Leon G. Higley \\ University of Nebraska-Lincoln, Ihigley1@unl.edu \\ Fikru J. Haile \\ Dow AgroSciences
}

Follow this and additional works at: https://digitalcommons.unl.edu/entomologyfacpub

Part of the Entomology Commons

Hunt, Thomas E.; Higley, Leon G.; and Haile, Fikru J., "Imported Longhorned Weevil (Coleoptera:

Curculionidae) Injury to Soybean: Physiological Response and Injury Guild-Level Economic Injury Levels" (2003). Faculty Publications: Department of Entomology. 294.

https://digitalcommons.unl.edu/entomologyfacpub/294

This Article is brought to you for free and open access by the Entomology, Department of at DigitalCommons@University of Nebraska - Lincoln. It has been accepted for inclusion in Faculty Publications: Department of Entomology by an authorized administrator of DigitalCommons@University of Nebraska - Lincoln. 


\title{
Imported Longhorned Weevil (Coleoptera: Curculionidae) Injury to Soybean: Physiological Response and Injury Guild-Level Economic Injury Levels
}

\author{
THOMAS E. HUNT, ${ }^{1}$ LEON G. HIGLEY, ${ }^{2}$ AND FIKRU J. HAILE ${ }^{3}$ \\ Department of Entomology, Haskell Agricultural Laboratory, University of Nebraska Northeast Research and Extension \\ Center, 57905866 Road, Concord, NE 68728
}

\begin{abstract}
J. Econ. Entomol. 96(4): 1168-1173 (2003)
ABSTRACT The imported longhorned weevil, Calomycterus setarius Roelofs, is an occasional pest of soybean, Glycine max (L.), and can cause substantial defoliation of seedling soybean when the weevil is present in large numbers. Because weevil populations can reach high levels, the potential exists for significant seedling injury, so economic injury levels (EILs) are needed for imported longhorned weevil on seedling soybean. Because the bean leaf beetle, Cerotoma trifurcata (Forster), also is present on seedling soybean, injury by this insect should be included in EIL calculations. This study was conducted to (1) determine daily soybean consumption rates of imported longhorned weevil; (2) compare soybean injury responses between weevil injured and noninjured soybeans; and (3) develop multiple species EILs for imported longhorned weevil and bean leaf beetle. Field and laboratory studies were conducted in 1997 to determine weevil daily consumption rates. Field experiments were conducted in 1998 to examine physiological responses of soybean to weevil injury. Field and laboratory consumption rates were 0.16 and $0.21 \mathrm{~cm}^{2}$ per day, respectively. There were no significant differences in physiological responses (i.e., photosynthetic rates, stomatal conductance, and transpiration rates) between noninjured soybean leaflets (caged) and weevil-injured leaflets. Multiple-species EILs were developed for imported longhorned weevil and bean leaf beetle on VC through V3 soybean.
\end{abstract}

KEY WORDS Calomycterus setarius, soybean, photosynthesis, Cerotoma trifurcata

THE IMPORTED LONGHORNED WEEVIL, Calomycterus setarius Roelofs, is an occasional pest of soybean, Glycine $\max (\mathrm{L}$.), that can cause substantial injury to seedling soybean when weevils are present in large numbers (Rice and Pilcher 1997). Since its introduction from Japan in 1929 (Mutchler 1930), the weevil has spread west from New England and Virginia to eastern Nebraska (Rice 1994). In the Midwest, adults emerge in grassy areas or pastures during mid-June (Frye 1961) and defoliate seedling soybean. When present in large numbers, it is common to observe $\geq 15$ weevils per seedling (T.E.H., unpublished data). The weevil is flightless and parthenogenetic (Johnson 1944). Spread of the weevil is slow, and soybean injury typically occurs along field margins (Rice 1994, Rice and Pilcher 1997). However, in 1997, injury occurred throughout some soybean fields in the first year removed from the Conservation Reserve Program in northeast Nebraska (T.E.H., unpublished data). Because seedlings are small and weevils can be quite

\footnotetext{
1E-mail: thunt2@unl.edu.

2 Department of Entomology, 202 Plant Industry Bldg., University of Nebraska, Lincoln, NE 68583.

${ }^{3}$ Dow AgroSciences, Western Research Center, 7521 W. California Ave., Fresno, CA 93706.
}

numerous, weevils and defoliation are easily observed and of concern to soybean producers.

Although seedling soybean has great compensatory capacity, economic damage can result when injury delays plant growth so that the critical leaf area index (when 90\% of light is intercepted) is not exceeded before the plant reaches reproductive stages (Hunt et al. 1994). Therefore, economic injury levels (EILs) are needed for imported longhorned weevil on seedling soybean. To develop accurate EILs, quantification of insect injury during the seedling stages is crucial. Fifty to $100 \%$ of soybean leaf tissue is expanding during the seedling stages (seedling stages are defined as stages for which $50 \%$ or more of the leaf tissue is expanding), therefore it also is important to consider leaf expansion (defoliation injury expands along with expanding leaf tissue). Leaf expansion matrices can be used to determine the final loss of leaf tissue after full leaf expansion resulting from insect injury (Hunt et al. 1995).

The EIL concept, first defined by Stern et al. (1959), has become a central principle of integrated pest management. To date, EILs for over 100 insect pests on 43 commodities have been developed (Peterson 1996). Almost all of these EILs are single-species EILs, which 
can present an implementation problem. Most crops are susceptible to a variety of pests throughout their growth period. Different pests may be present at levels below their respective EILs, but the sum result of their injury may cause economic damage. This problem is addressed in part by the use of injury guilds and multiple-species EILs (Pedigo et al. 1986, Hutchins et al. 1988, Hutchins and Funderburk 1991, Peterson et al. 1995, Peterson 1996). An injury guild is a collection of insect species that cause a common injury producing similar physiological responses in a plant. To be included in a guild, an insect species must (1) produce the same type of injury (e.g., an individual cannot feed on leaves and fruits during the same period), (2) produce injury during the same plant stage, (3) produce injury of similar intensity (e.g., within the same order of magnitude), and (4) produce injury to the same plant part at the same strata (e.g., injure leaves in the same level of the plant canopy). Multiple-species EILs can be developed by converting guild-member injuries into a common injury term (injury equivalent) and using this term in EIL calculations. In the Midwest, both adult imported longhorned weevil and adult bean leaf beetle, Cerotoma trifurcata (Forster), defoliate seedling soybean by removing leaf tissue. Physiological responses (e.g., photosynthetic rates) of soybean to insect defoliation have been demonstrated to be similar across several insect defoliators, such as adult bean leaf beetle, adult soybean leafminer (Odontota horni Smith), redlegged grasshopper [Melanoplus fumurrubrum (DeGeer)], soybean looper [Pseudoplusia includens (Walker)], velvetbean caterpillar [Anticarsia gemmatalis (Hubner)], and green cloverworm [Hypena scabra (F.)] (L.G.H., unpublished data). Because the injury caused by imported longhorned weevil and bean leaf beetle to seedling soybean is physically and temporally similar, we believe these insects fulfill the requirements that constitute an injury guild and can provide an example of multiplespecies EILs for defoliators of seedling soybean.

Currently, there are no established consumption rates or EILs for imported longhorned weevil on seedling soybean. Also, the possibility exists for adult imported longhorned weevil and adult bean leaf beetle to occur together on seedling soybean. This presents the potential for their combined injury to result in economic injury. Consequently, the objectives of this research were to (1) determine the daily consumption rate for adult imported longhorned weevil on soybean, (2) determine the final loss of leaf tissue resulting from imported longhorned weevil injury and leaf expansion, (3) determine the physiological response of soybean to imported longhorned weevil injury, and (4) develop multiple-species EILs for imported longhorned weevil and bean leaf beetle on seedling soybean.

\section{Materials and Methods}

Consumption Studies. 'Dunbar' soybean was planted at the University of Nebraska-Lincoln East Campus experimental fields on 17 May 1997, in Zook silty clay loam (fine, montmorillonitic mesic cumulic Haphaquoll). The field was plowed once the previous fall and disked twice in the spring. A tank mix of alachlor (2.13 kg AI/ha) and metribuzin (5.1 kg AI/ ha) was applied for weed control before planting. Row orientation was north-south. Row width was $76 \mathrm{~cm}$, and planting density was 25 plants per row-m.

Adult weevils were collected from seedling soybean and held overnight at room temperature. Seventy-five weevils were taken to the field and placed in groups of five into $6.5-\times 8.0$-cm nylon mesh envelopes (seven squares per $\mathrm{cm}$ mesh size). Fifteen plants were randomly selected and each envelope was taped around a fully expanded leaflet. A leaflet enclosed by a mesh envelope represented the experimental unit. Every morning for $7 \mathrm{~d}$ weevil mortality was recorded, the envelopes were moved to new plants and secured to fully expanded leaflets, and the dead weevils were replaced. Mean daily temperatures were recorded.

The old leaflets were taken to the lab and photocopied. Leaf area consumed was measured with a microcomputer-based digital imaging system and digital analysis software (Sigmascan Pro, SPSS Science, Chicago, IL). The area measured for each experimental unit was divided by five to obtain consumption per weevil per day. When a dead weevil was found, the area was divided by the number of remaining live weevils.

For laboratory measures of consumption, 30 fully expanded soybean leaves were removed in the field, placed in water pics, and returned to the lab. A leaflet on each leaf was enclosed in a nylon mesh envelope containing five weevils and placed in an environmental chamber $\left(23^{\circ} \mathrm{C}, \approx 60 \% \mathrm{RH}\right.$, photoperiod $14: 10 \mathrm{~h}$ L:D). Every morning for $10 \mathrm{~d}$ weevil mortality was recorded and new leaves were provided. The old leaves were photocopied. Leaf area measurements and consumption rates were determined as described above.

Both field and laboratory experiments had a completely randomized design, with 15 and 30 replications, respectively. Values for each replicate represent the mean consumption of five beetles over $7 \mathrm{~d}$ (field) and $10 \mathrm{~d}$ (laboratory). The laboratory experiment was conducted as a back-up in the event that inclement weather confounded the field experiment.

Physiological Response to Injury. Dunbar soybean was planted at the University of Nebraska-Lincoln East Campus experimental fields on 26 May 1998, in Zook silty clay loam. Field preparation and planting was the same as in 1997.

Experimental design was completely random with six replications. Treatments were noninjured, noncaged leaflet; noninjured, caged leaflet; and an injured, caged leaflet. Experimental units were the central leaflet of a trifoliolate on the second or third node of a V5 soybean plant. For the injured treatment, 20 weevils were placed on a caged leaflet on 2 July and allowed to feed for $24 \mathrm{~h}$.

Photosynthetic rate, stomatal conductance, and transpiration rate of treatment leaflets were measured using a portable photosynthetic system (model LI- 
6400, LiCor, Lincoln, NE). Measurements were taken $2 \mathrm{~h}, 1 \mathrm{~d}$, and $3 \mathrm{~d}$ after weevils were removed from leaflets. Curves of apparent photosynthesis versus increasing photosynthetically active radiation (PAR) (light response curves) were taken $3 \mathrm{~h}$ after the weevils were removed, and curves of apparent photosynthesis versus intercellular $\mathrm{CO}_{2}$ concentration (referred to as $\mathrm{A}-\mathrm{C}_{\mathrm{i}}$ ) curves were taken $4 \mathrm{~h}$ after the weevils were removed. The light response and $A-C_{i}$ curves provided a more detailed measure of photosynthetic responses by injured and noninjured leaves, and, if treatment differences were observed, these curves would help indicate where photosynthetic processes were altered (e.g., via stomatal limitations or mesophyll limitations).

Statistical analyses were conducted using analysis of variance. Means were separated by protected least significant difference $(P=0.05)$.

\section{Results and Discussion}

Daily Leaf Area Consumption. The mean laboratory consumption rate of imported longhorned weevils was $0.15 \pm 0.01(\mathrm{SE}) \mathrm{cm}^{2} / \mathrm{d}$ per weevil and the mean field consumption rate was $0.21 \pm 0.02(\mathrm{SE})$ $\mathrm{cm}^{2} / \mathrm{d}$. There was a significant difference between mean daily consumption rate between field and laboratory means $(F=11.4 ; \mathrm{df}=1,355 ; P<0.0008)$. The mean daily temperature during the field study was $26.8^{\circ} \mathrm{C}, 3.8^{\circ} \mathrm{C}$ higher than during the laboratory study. Increased temperature, and consequently increased weevil metabolism, may explain the higher field consumption rate. An increase in consumption with increasing temperature has been observed for bean leaf beetle on soybean in the spring (Hunt et al. 1995). A consumption rate of $0.21 \mathrm{~cm}^{2} / \mathrm{d}$ was used for calculation of EILs for imported longhorned weevil on seedling soybean.

The total leaf injury caused by a single weevil on a seedling soybean can be calculated by multiplying the daily consumption rate $\left(0.21 \mathrm{~cm}^{2} / \mathrm{d}\right)$ by the number of days during the seedling stage that the weevil feeds. For example, using a 14-d seedling period (soybean stage V1 through V3), the mean leaf area an adult imported longhorned weevil would consume is 2.94 $\mathrm{cm}^{2}$.

Final Leaf Tissue Loss After Leaf Expansion. Seedling soybean leaves take $\approx 8 \mathrm{~d}$ to fully expand after unfolding (Kumara 1969). Injury (leaf area removed) during this period will expand along with the leaf tissue. Also, the occurrence of injury causes a slight reduction of leaf expansion (Hunt et al. 1995). Taking this into account, Hunt et al. (1995) constructed an injury expansion coefficient (IEC) matrix (Table 1, adapted from Hunt et al. 1995) for seedling soybean, recognizing daily changes in the IEC by leaf (unifoliolates through third trifoliolate). Upon unfolding, a seedling leaf has an IEC of 8.5; i.e., a $1-\mathrm{cm}^{2}$ hole (defoliation injury) created at this time will become an $8.5-\mathrm{cm}^{2}$ hole when the leaf is fully expanded. Each subsequent day the IEC is reduced until full leaf ex-
Table 1. Daily injury expansion coefficients for the unifoliolate (U), first (T1), second (T2), and third (T3) trifoliolate leaves of soybean (adapted from Hunt et al. 1995)

\begin{tabular}{|c|c|c|c|c|c|}
\hline \multirow{2}{*}{$\begin{array}{l}\text { Growth } \\
\text { Stage }\end{array}$} & \multirow{2}{*}{ Day } & \multicolumn{4}{|c|}{ Injury Expansion Coefficient } \\
\hline & & $\mathrm{U}$ & $\mathrm{T} 1$ & $\mathrm{~T} 2$ & T3 \\
\hline \multirow[t]{5}{*}{$\mathrm{VC}$} & 0 & 8.85 & & & \\
\hline & 1 & 4.63 & & & \\
\hline & 2 & 3.13 & & & \\
\hline & 3 & 2.37 & & & \\
\hline & 4 & 1.90 & & & \\
\hline \multirow[t]{5}{*}{ V1 } & 5 & 1.59 & 8.85 & & \\
\hline & 6 & 1.37 & 4.52 & & \\
\hline & 7 & 1.20 & 3.04 & & \\
\hline & 8 & 1.07 & 2.29 & & \\
\hline & 9 & 1.00 & 1.83 & & \\
\hline \multirow[t]{5}{*}{$\mathrm{V} 2$} & 10 & 1.00 & 1.53 & 8.85 & \\
\hline & 11 & 1.00 & 1.31 & 4.57 & \\
\hline & 12 & 1.00 & 1.15 & 3.08 & \\
\hline & 13 & 1.00 & 1.02 & 2.33 & \\
\hline & 14 & 1.00 & 1.00 & 1.87 & \\
\hline \multirow[t]{5}{*}{$\mathrm{V} 3$} & 15 & 1.00 & 1.00 & 1.56 & 8.85 \\
\hline & 16 & 1.00 & 1.00 & 1.34 & 4.17 \\
\hline & 17 & 1.00 & 1.00 & 1.17 & 2.73 \\
\hline & 18 & 1.00 & 1.00 & 1.04 & 2.03 \\
\hline & 19 & 1.00 & 1.00 & 1.00 & 1.61 \\
\hline
\end{tabular}

pansion. At full leaf expansion the IEC $=1$ until leaf senescence.

To use the IEC matrix, one must determine (1) whether the insect's daily consumption varies through time (e.g., different rates for different stadia), (2) the probability of a given leaf being fed on for each day, and (3) where in the seedling canopy the insect under study feeds (e.g., expanded versus expanding leaves). For an adult weevil on seedling soybean, the daily consumption rate is assumed to be constant during the seedling stages. Imported longhorned weevils, like bean leaf beetles, appear to feed primarily on expanding, tender leaves of seedling soybean, so only IECs of these expanding leaves will be considered. We assumed that an equal chance exists each day for an insect to feed on any expanding leaf. Given these assumptions, mean IECs can be calculated for defoliation injury during various seedling periods through V3. For example, the mean IEC for expanding leaves the period VC through V3 is the sum of all IECs $>1$ from day 0 through day 19 , divided by the number of IECs considered, or mean IEC $=96.85 / 32=3.03$.

This indicates that the final tissue loss resulting from an adult weevil feeding from VC through V3 is approximately three times the initial injury. Mean IECs for soybean stages VC through V3 and the final leaf tissue loss per weevil and bean leaf beetle are presented in Table 2.

Physiological Response to Injury. Imported longhorned weevil defoliation injury ranged from $14.2 \%$ to $34.6 \%$. There were no significant differences in photosynthetic rate or stomatal conductance between treatment means $2 \mathrm{~h}, 1 \mathrm{~d}$, or $3 \mathrm{~d}$ postinjury (Table 3 ). There were no significant differences in transpiration rate between treatment means $1 \mathrm{~d}$ postinjury. There were significant differences in transpiration rate between treatment means $2 \mathrm{~h}$ and $3 \mathrm{~d}$ postinjury. At the 2 -h reading, the mean transpiration rate of the non- 
Table 2. Imported longhorned weevil and bean leaf beetle leaf consumption and final injury after leaf expansion of soybean

\begin{tabular}{|c|c|c|c|c|}
\hline Defoliator & $\begin{array}{c}\text { Soybean } \\
\text { growth stage }^{a}\end{array}$ & $\begin{array}{c}\text { Total consumption at } \\
\text { end of V3 }\left(\mathrm{cm}^{2}\right)^{b}\end{array}$ & Mean IEC & $\begin{array}{l}\text { Final tissue loss at } \\
\text { end of V3 }\left(\mathrm{cm}^{2}\right)\end{array}$ \\
\hline \multirow[t]{4}{*}{ Imported longhorned weevil } & $\mathrm{VC}$ & 3.99 & 3.03 & 12.09 \\
\hline & $\mathrm{V} 1$ & 2.94 & 2.81 & 8.26 \\
\hline & $\mathrm{V} 2$ & 1.89 & 2.79 & 5.27 \\
\hline & $\mathrm{V} 3$ & 0.84 & 2.72 & 2.28 \\
\hline \multirow[t]{4}{*}{ Bean leaf beetle } & $\mathrm{VC}$ & 5.89 & 3.03 & 17.85 \\
\hline & $\mathrm{V} 1$ & 4.34 & 2.81 & 12.20 \\
\hline & $\mathrm{V} 2$ & 2.79 & 2.79 & 7.78 \\
\hline & $\mathrm{V} 3$ & 1.24 & 2.72 & 3.37 \\
\hline
\end{tabular}

${ }^{a}$ Feeding days for $\mathrm{VC}=19$, for $\mathrm{V} 1=14$, for $\mathrm{V} 2=9$, and for $\mathrm{V} 3=4$

${ }^{b}$ Imported longhorned weevil consumption rate $=0.21 \mathrm{~cm}^{2} / \mathrm{d}$; Bean leaf beetle consumption rate $=0.31 \mathrm{~cm}^{2} / \mathrm{d}(\mathrm{Hunt}$ et al. 1995$)$.

caged control leaflets was significantly higher than that of the caged injured leaflets (Table 3). At the 3-d reading, the mean transpiration rate of the noncaged control leaflets was significantly higher than that of the caged control and caged injured leaflets (Table 3). However, in both cases there was no significant difference between the mean transpiration rates of the caged control and caged injured leaflets. Light response curves and A-Ci response curves of injured and control (caged) plants were similar (Fig. 1).

Injury Guild-Level EILs. Injury guild-level EILs were developed using the guild-EIL methodology of Hutchins et al. (1988) and Hutchins and Funderburk (1991). The injury per insect for imported longhorned weevil and bean leaf beetle was placed on a common basis through an injury equivalency system. Because the bean leaf beetle is a common seedling soybean pest, it is used as a standard equivalency species and the weevil was related to this standard on a basis of its consumption potential. One injury equivalent equals the injury caused by one bean leaf beetle during the respective seedling stages. The number of injury equivalents for one weevil was 0.68 (weevil consumption/beetle consumption). The injury equivalents of a mixed sample of weevils and beetles was therefore

$$
\begin{aligned}
\text { Injury equivalents } & =(1.00) \times \text { beetles } / \text { plant }) \\
& +(0.68 \times \text { weevils } / \text { plant }) .
\end{aligned}
$$

The EILs are in injury equivalents and are calculated based on the formula

$$
\mathrm{EIL}=\mathrm{C} / \mathrm{VKD}\left(\mathrm{I}_{\mathrm{t}}\right)
$$

where $\mathrm{C}=$ cost of management $(\$ / \mathrm{ha}), \mathrm{V}=$ market value per production unit $(\$ / \mathrm{kg}), \mathrm{K}=$ proportionate reduction of injury, and $D\left(I_{t}\right)=$ yield loss $(\mathrm{kg} / \mathrm{ha})$ as a function of $I_{t}$ (total injury; i.e., $\mathrm{cm}^{2}$ leaf area loss per plant at late V3).

Proportionate reduction of injury $(\mathbf{K})$ is essentially proportionate to reduction of the insect population, and will depend on factors such as insecticide selection and coverage. Insecticide coverage during most seedling stages should be near complete, so for our purposes $K=1$ ( $100 \%$ control). This would be most appropriate for soybeans planted in ground that was previously Conservation Reserve Program or pasture. When injury is being caused by a steady migration of weevils into the soybeans from grassy field borders, $\mathrm{K}$ will effectively decrease along field margins. In addition, efficacy of various insecticides against imported

\begin{tabular}{|c|c|c|c|}
\hline \multirow{2}{*}{ Treatment } & \multicolumn{3}{|c|}{ Physiological measurements } \\
\hline & $2 \mathrm{~h}$ post-injury & $1 \mathrm{~d}$ post-injury & $3 \mathrm{~d}$ post-injury \\
\hline & \multicolumn{3}{|c|}{ Photosynthetic rate, $\mu$ mole $\mathrm{CO}_{2}$ fixed $\mathrm{m}^{-2} \mathrm{~s}^{-1}$} \\
\hline Uncaged control & $28.4(0.9)$ & $28.3(1.4)$ & $27.8(0.9)$ \\
\hline Caged control & $25.7(1.1)$ & $28.3(1.0)$ & $29.0(0.9)$ \\
\hline Caged injured & $25.5(1.4)$ & $29.1(0.9)$ & $28.8(1.2)$ \\
\hline \multirow[t]{2}{*}{$F$ value } & $1.55 \mathrm{NS}$ & $0.19 \mathrm{NS}$ & $0.59 \mathrm{NS}$ \\
\hline & \multicolumn{3}{|c|}{ Stomatal conductance, $\mathrm{mol} \mathrm{H}_{2} \mathrm{O} \mathrm{m}^{-2} \mathrm{~s}^{-1}$} \\
\hline Uncaged control & $1.22(0.13)$ & $1.14(0.11)$ & $1.50(0.07)$ \\
\hline Caged control & $1.11(0.11)$ & $1.27(0.08)$ & $1.54(0.06)$ \\
\hline Caged injured & $1.11(0.11)$ & $1.37(0.06)$ & $1.67(0.06)$ \\
\hline \multirow[t]{2}{*}{$F$ value } & $0.34 \mathrm{NS}$ & $2.36 \mathrm{NS}$ & $1.60 \mathrm{NS}$ \\
\hline & \multicolumn{3}{|c|}{ Transpiration rate, $\mathrm{mol} \mathrm{H}_{2} \mathrm{O} \mathrm{m}^{-2} \mathrm{~s}^{-1}$} \\
\hline Uncaged control & $14.9(0.8) \mathrm{a}$ & $11.3(0.3)$ & $18.8(0.2) \mathrm{a}$ \\
\hline Caged control & $13.5(0.5) \mathrm{ab}$ & $10.5(0.3)$ & $17.6(0.2) \mathrm{b}$ \\
\hline Caged injured & $12.7(0.6) b$ & $10.5(0.3)$ & $17.3(0.5) b$ \\
\hline$F$ value & $4.11 *$ & $1.92 \mathrm{NS}$ & $14.26^{*}$ \\
\hline
\end{tabular}

Table 3. Mean $( \pm \mathrm{SE})$ photosynthetic rate, stomatal conductance, and transpiration rate of noninjured and imported longhorned weevil-injured soybean leaflets

* $P \leq 0.05 ; \mathrm{NS}, P>0.05$. Means followed by the same letter are not significantly different (protected LSD, $P<0.05$ ). For each measurement group the $F$ value is presented in the table, $\mathrm{df}$ for treatment $=2$, and $\mathrm{df}$ for error $=10$. 

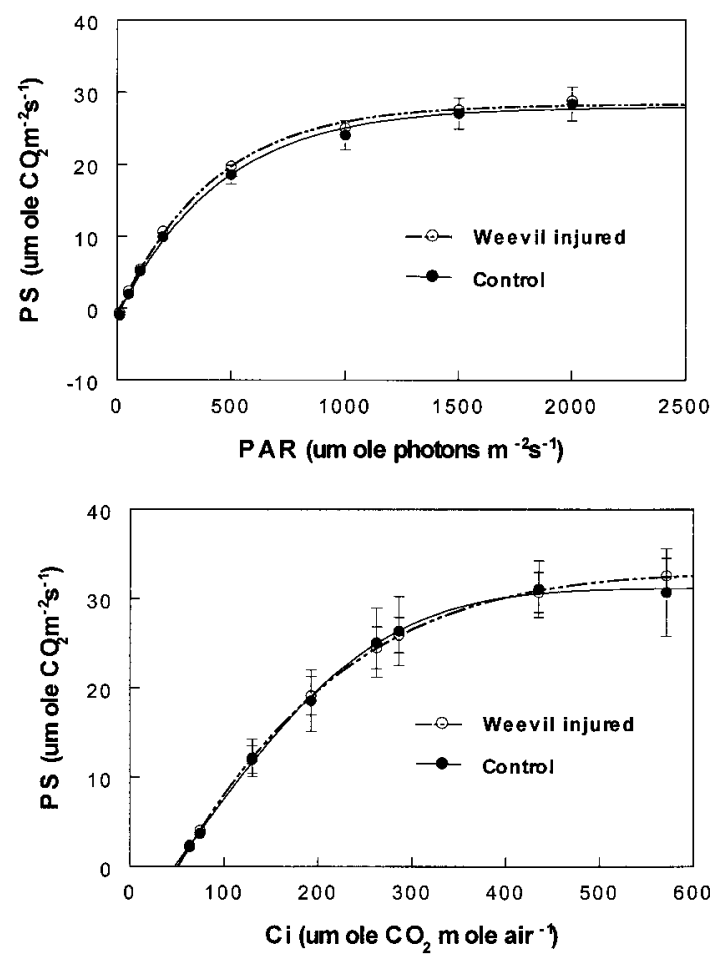

Fig. 1. Light curves [photosynthetic rate (PS) by photosynthetically active radiation (PAR)] and intercellular $\mathrm{CO}_{2}$ concentration $(\mathrm{Ci})$ curves (PS by $\mathrm{Ci}$ ) for imported longhorned weevil injured and noninjured soybean leaves. Light curves were taken $3 \mathrm{~h}$ after weevils were removed, and intercellular $\mathrm{CO}_{2}$ concentration curves were taken $4 \mathrm{~h}$ after weevils were removed. Bars indicate standard error.

longhorned weevil requires study, as initial studies indicate low efficacy for several common insecticides (Rice and Pilcher 1997).

Yield loss as a function of injury $\left[\mathrm{D}\left(\mathrm{I}_{\mathrm{t}}\right)\right]$ can be calculated by multiplying the damage per unit injury
(D) of $1.33 \mathrm{~kg} \mathrm{ha}^{-1}$ per $\mathrm{cm}^{2}$ of leaf tissue loss per plant at late V3 (Hunt et al. 1995, from regression based on $34.4 \mathrm{bu} \mathrm{ac}^{-1}$ ) by the total leaf area loss caused by an insect feeding from a specific $\mathrm{V}$ stage through V3 $\left(\mathrm{I}_{\mathbf{t}}\right)$ (Table 2). Because we are using bean leaf beetle as the basis for our injury equivalents, leaf area loss associated with bean leaf beetle will be used in the EIL calculations. For example, a bean leaf beetle feeding from V1 through V3 results in a $12.20 \mathrm{~cm}^{2}$ tissue loss per plant, so $\left(1.33 \mathrm{~kg} \mathrm{ha}^{-1}\right.$ per $\left.\mathrm{cm}^{2}\right)\left(12.20 \mathrm{~cm}^{2}\right)=$ $16.23 \mathrm{~kg} \mathrm{ha}^{-1}$ yield loss.

If the expected yield is significantly different from $34.4 \mathrm{bu} \mathrm{ac}^{-1}$, the percent yield loss versus leaf area loss $\left(\mathrm{cm}^{2}\right.$ plant $\left.^{-1}\right)$ regression, forced through zero, can be used to obtain a damage term based on percent loss. The regression equation is $y=0.0577 x\left(R^{2}=0.86\right.$, $P>F=0.0001)$.

Economic variables $\mathrm{V}$ and $\mathrm{C}$ fluctuate with changing economic conditions and management choices, so an EIL matrix was constructed to reflect these changes (Table 4). Assuming a V of $\$ 0.25 \mathrm{~kg}^{-1}\left(\$ 6.50 \mathrm{bu}^{-1}\right)$, a C of $\$ 14.83 \mathrm{ha}^{-1}\left(\$ 6.00 \mathrm{acre}^{-1}\right)$, a K of 1 , and a D( $\left.\mathrm{I}_{\mathrm{t}}\right)$ of $16.23 \mathrm{~kg} \mathrm{ha}^{-1}$, the EIL is 3.8 injury equivalents plant $^{-1}$ for beetle and weevils on a V1 soybean plant. If field sampling found an average of 2.5 bean leaf beetles and 2.0 imported longhorned weevils per plant, the respective injury equivalents per plant from equation 1 would be $(1.00)(2.5)+(0.68)(2)=3.86$ injury equivalents per plant

This is slightly above the EIL (Table 4). Because economic thresholds are typically set below the EIL, in this case treatment of the soybean field may be warranted. If treatment were to be simply based on the EILs for each of the individual insect species, the field might not be treated when indeed treatment was warranted.

The imported longhorned weevil and the bean leaf beetle can both be present in soybean fields at the same time. Because soybean physiological responses to their injury are similar and the injury is physically and temporally similar, these insects can be included

Table 4. Multiple-species economic injury levels (EIL) for imported longhorned weevil and bean leaf beetle expressed in injury equivalents per plant for $\mathrm{VC}, \mathrm{V1}, \mathrm{V} 2$, and $\mathrm{V} 3$ soybean. Injury equivalents $=(1.00 \times$ beetles/plant $)+(0.68 \times$ weevils/plant $)$

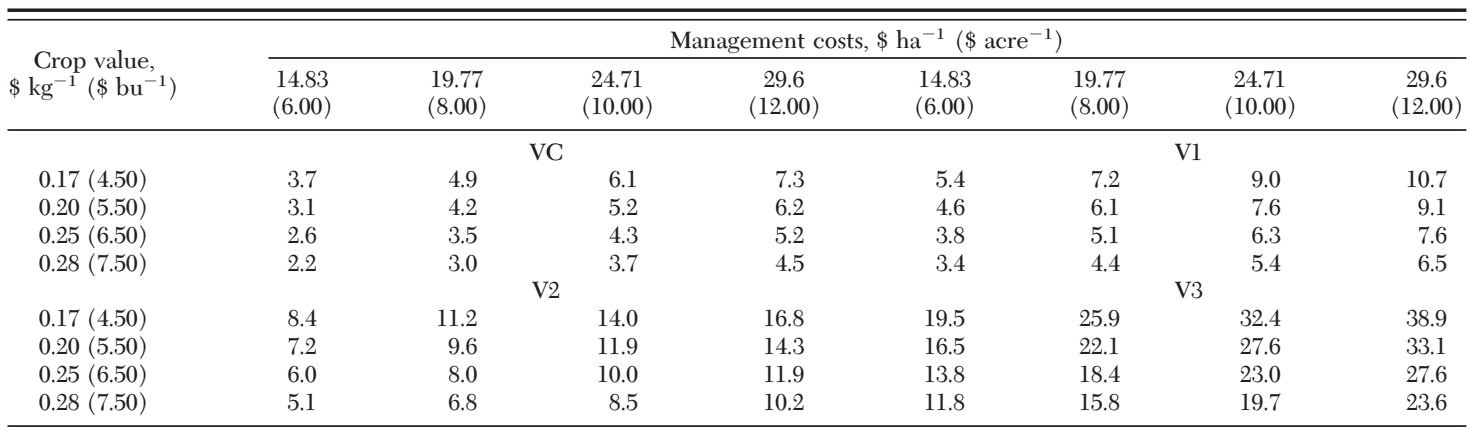

$\mathrm{EIL}=\mathrm{C} / \mathrm{VKD}\left(\mathrm{I}_{\mathrm{t}}\right)$ where for: $\mathrm{VC}, \mathrm{D}=1.33$ (Hunt et al. 1995, from regression based on $34.4 \mathrm{bu} \mathrm{ac}^{-1}$ ), $\mathrm{I}_{\mathrm{t}}=17.85, \mathrm{~K}=1 ; \mathrm{V1}, \mathrm{D}=1.33, \mathrm{I}_{\mathrm{t}}=$ $12.20, \mathrm{~K}=1 ; \mathrm{V} 2, \mathrm{D}=1.33, \mathrm{I}_{\mathrm{t}}=7.78, \mathrm{~K}=1 ; \mathrm{V} 3, \mathrm{D}=1.33, \mathrm{I}_{\mathrm{t}}=3.37, \mathrm{~K}=1$. For injury equivalents/row-foot multiply by 7.62 ; for injury equivalents/row-m multiply by 25 . If the expected yield is significantly different from 34.4 bu ac $^{-1}$, the percent yield loss vs. leaf area loss $\left(\mathrm{cm}^{2}\right.$ plant $^{-1}$ ) regression, forced through zero, can be used to obtain a damage term based on percent loss. The regression equation is $y=0.0577 x$ $\left(R^{2}=0.86, P>F=0.0001\right)$. 
in the same injury guild. The multiple-species EILs presented here will provide soybean producers a tool that considers the combined effects of the imported longhorned weevil and bean leaf beetle on seedling soybean.

\section{Acknowledgments}

We thank Tina Svatos, Bridget Barclay, and Ramneek Bhogal (University of Nebraska-Lincoln) for technical assistance during this study, and Drs. Robert J. Wright and Robert K.D. Peterson for initial reviews of this manuscript. This is Journal Series No. 13825 of the Nebraska Agricultural Research Division and Contribution No. 1133 of the Department of Entomology, University of Nebraska-Lincoln.

\section{References Cited}

Frye, R. D. 1961. Biology and control of Calomycterus setarius Roelofs. M. S. thesis, Iowa State University, Ames, IA.

Hunt, T. E., L. G. Higley, and J. F. Witkowski. 1994. Soybean growth and yield responses to simulated bean leaf beetle injury to seedlings. Agron. J. 86: 140-146.

Hunt, T. E., L. G. Higley, and J. F. Witkowski. 1995. Bean leaf beetle injury to seedling soybean: consumption, effects of leaf expansion, and economic injury levels. Agron. J. 87: 183-188.

Hutchins, S. H., L. G. Higley, and L. P. Pedigo. 1988. Injury equivalency as a basis for developing multiple-species economic injury levels. J. Econ. Entomol. 81: 1-8.

Hutchins, S. H., and J. E. Funderburk. 1991. Injury guilds: a practical approach for managing pest losses to soybean. Agric. Zool. Rev. 4: 1-21.
Johnson, J. P. 1944. The imported longhorned weevil, Calomycterus setarius Roelofs, pp. 121-142. Conn. Agr. Expt. Sta. Bull. 479.

Kumara, A. 1969. Studies on dry matter production in soybean plant: V. Photosynthetic system of soybean plant population. Proc. Crop Sci. Soc. Jpn. 33: 467-472.

Mutchler, A. J. 1930. A Japanese weevil, Calomycterus setarius Roelofs, which may become a pest in the United States. Am. Mus. Novitates No. 418: 1-3.

Pedigo, L. P., S. H. Hutchins, and L. P. Higley. 1986. Economic injury levels in theory and practice. Annu. Rev. Entomol. 31: 341-368.

Peterson, R.K.D., L. G. Higley, and S. D. Danielson. 1995. Alfalfa consumption by adult clover leaf weevil (Coleoptera: Curculionidae) and development of injury equivalents for stubble defoliators. J. Econ. Entomol. 88: 1441-1444.

Peterson, R.K.D. 1996. The status of economic-decisionlevel development, pp. 151-178. In L. G. Higley, and L. P. Pedigo [ (eds.] Economic thresholds for integrated pest management. University of Nebraska Press, Lincoln, NE.

Rice, M. E. 1994. Imported longhorned weevil, pp. 63-64. In L. G. Higley and D. J. Boethel [eds. [rsab] Handbook of soybean insect pests. Entomological Society of America, Lanham, MD.

Rice, M. E., and C. D. Pilcher. 1997. Imported longhorned weevil, Calomycterus setarius, defoliation and damage to soybean in Iowa. J. Kansas Entomol. Soc. 70: 272-280.

Stern, V. M., R. F. Smith, R. Van Den Bosch, and K. S. Hagen. 1959. The integrated control concept. Hilgardia 29: 81101.

Received for publication 19 August 2002; accepted 15 April 2003. 